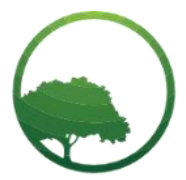

Business \& Social Science IJRBS

\section{Research in Business \& Social Science}

IJRBS VOL 10 NO 4 ISSN: 2147-4478

Available online at www.ssbfnet.com

Journal homepage: https://www.ssbfnet.com/ojs/index.php/ijrbs

\title{
Desired characteristics of successful start-up entrepreneurs in Prachuap Kirikhan province
}

\author{
(iD) Kanjana Punoiam ${ }^{(a) *(1)}$ Bundit Anuyahong ${ }^{(b)}$ (D) Wipanee Pengnate ${ }^{(c)}$ (D) Supaporn \\ Phatratkul $^{(d)}$ (D) Chatchawal Sangthongluan ${ }^{(e)}$ \\ (a) Assistant Professor Dr., Business Administration (Management), Faculty of Business Administration, Rajamangala University of Technology \\ Rattanakosin, Wang Klai Kangwon Campus, Prachup Kirikhan, Thailand. \\ ${ }^{(b, c)}$ Assistant Professor(s), Dr., English Department, College of General Education and Languages, Thai-Nichi Institute of Technology Bangkok, \\ Thailand \\ ${ }^{(d)}$ Business Administration (Management), Faculty of Business Administration, Rajamangala University of Technology Rattanakosin, Wang Klai \\ Kangwon Campus, Prachup Kirikhan, Thailand \\ ${ }^{(e)}$ Dr., College of Innovative Management (R-CIM), Rajamangala University of Technology Rattanakosin, Wang Klai Kangwon Campus, Prachup \\ Kirikhan, Thailand
}

\author{
A R TICLE INFO \\ Article history: \\ Received 30 April 2021 \\ Received in rev. form 23 May 2021 \\ Accepted 27 May 2021 \\ Keywords: \\ Desired characteristics of Start-up \\ Entrepreneurs, Start-up Entrepreneurs, \\ Start-up Entrepreneurs in Prachuap \\ Kirikhan Province \\ JEL Classification: \\ O15
}

\begin{abstract}
A B S T R A C T
This study aims to (i) analyze desired characteristics of successful start-up entrepreneurs in Prachuap Kirikhan province, (ii) compare desired characteristics of successful start-up entrepreneurs in Prachuap Kirikhan province according to gender, age, educational background, investment, budget capital, entrepreneur experience, and a number of staff, and (iii) study additional suggestions. The research samples were 140- start-up entrepreneurs in Prachuap Kirikhan province derived through the Simple Random Sampling technique. The instruments used for collecting the data were the rating scale and open-ended questionnaire. Frequency, mean scores, Standard Deviation, $t$-Test, $F$-test, and content analysis were used for data analysis. The findings were (i) Desired characteristics of successful start-up entrepreneurs were at a high level (ii) Success of start-up business were ranked according to gender, educational background and number of staff and (iii) the additional suggestions were remarkably emphasized on using past and present experiences to adapt with the business; using technological advancement to reach a wider target group, and using new creativity and risk-taking to make a brand uniqueness.
\end{abstract}

(C) 2021 by the authors. Licensee SSBFNET, Istanbul, Turkey. This article is an open access article distributed under the terms and conditions of the Creative Commons Attribution (CC BY) license (http://creativecommons.org/licenses/by/4.0/).

\section{Introduction}

The trend toward the increasing importance of venture start-up in the global economy shows not only a strengthened business environment for them but also enhanced entrepreneurial enthusiasm among them. For this trend to continue and not be a temporary phenomenon, venture start-up must continue to grow and be competitive to survive (Lawless, 2014; Tengeh and Nkem, 2017). Moreover, the growth of online and mobile businesses, as well as the development not only of the cultural and creative but also the content and knowledge industries, has expanded and diversified existing business models and created new ones, triggering new business model interpretations and discussions (Jeon and Nah, 2014). These changes constitute the most important aspect of the Fourth Industrial Revolution, which is essentially equivalent to the evolution of the Internet of Things (IoT). Lee et al. stated that as the Fourth Industrial Revolution is under way, the width and speed of open innovation and the emergence of new combination business models are expected to exponentially increase (Kodama and Shibata, 2017). Canabal and O'Donnell (2009), further, demonstrate different motivation theories which attempt to explain the employee's behaviour in general. The review of the literature proves that having an entrepreneurial psychological profile makes a strong difference.

* Corresponding author. ORCID ID: 0000-0001-8094-4578

(C) 2021by the authors. Hosting by SSBFNET. Peer review under responsibility of Center for Strategic Studies in Business and Finance. https://doi.org/10.20525/ijrbs.v10i4.1167 
According the notion of Franke and Lüthje (2004), entrepreneurs are the engine of economic growth and development, in both developing and developed countries as these entrepreneurs are the great asset of companies which lead to a great impact on socioeconomic development. This is relevant to the notion of Deakins (1999) who describes entrepreneurs as people who organize, own, manage and assume the risk of an economic venture. The leadership school views entrepreneurs as leaders of people who have the ability to adapt their style to the needs of people whereas the intrapreneurship school posits that entrepreneurial skills can be useful in complex organizations through the development of independent units that create market and expand services.

As mentioned above, entrepreneurship is playing a significant role in economic development (Farsi et al., 2012) as it is recognized as the engine of economic growth and is positively related to economic growth through job creation, firm survival and technological change (Thurik, 2009; Etzkowitz, 2003). Generally speaking, entrepreneurial research is divided into to two main categories: 1) the personal traits or characteristics of the entrepreneur; and 2) the influence of cultural, political, social and economic contextual factors (Mazzarol et al., 1999). However, empirical studies done in the field of entrepreneurship investigating characteristics of entrepreneurs almost outnumber any other kinds of studies in the field (Othman et al., 2006). Numerous studies have accumulated on defining entrepreneurs in terms of their traits and characteristics such as creativity (Gibb, 1993), risk taking (McClelland, 1965; Palmer, 1971; Welsh and White, 1981), visionary (Kao, 1989), opportunity seeking (Peterson, 1985; Shane and Venkataraman, 2001), and so on.

Therefore, studies performed with a focus on trait approach attempt to identify a single personality trait or constellation of traits capable of successfully predicting entrepreneurial behaviour patterns and also to distinguish the entrepreneur from other groups are remarkably essential to consider the key factors to explaining entrepreneurship as a phenomenon.

The purposes of this study were:

1) to analyze desired characteristics of successful start-up entrepreneurs in Prachuap Kirikhan province,

2) to compare desired characteristics of successful start-up entrepreneurs in Prachuap Kirikhan province according to gender, age, educational background, investment, budget capital, Entrepreneur experience and number of staff, and

3) to study additional suggestions.

\section{Research and Methodology}

This study focused on desired characteristics of successful start-up entrepreneurs in Prachuap Kirikhan province which consists of the research samplings of 140- start-up entrepreneurs Prachuap Kirikhan provinces derived through Simple Random Sampling technique.

\section{Instrumentation}

The instruments used for gathering the data were the rating-scale and open-ended questionnaire based on desired characteristics of successful start-up entrepreneurs in Prachuap Kirikhan province. The first part (Part 1) of the questionnaire asked for the demographic information of the respondents: Gender, Age, Educational background, Investment, Budget capital, Entrepreneur experience and Number of staffs. The second part (Part 2) concerned desired characteristics of successful start-up entrepreneurs in Prachuap Kirikhan province. The five levels of desired characteristics of successful start-up entrepreneurs in Prachuap Kirikhan province were used in the questionnaire were ranked as "The highest level", "High level", "Moderate level", "Low level", and "The lowest level". Responses from the questionnaires were subsequently coded. The data of the respondents' coded responses were statistically calculated and analysed.

\section{Data Analysis}

Data analysis from questionnaire both single item and whole questionnaire which presented by a form of rating scale. These rating scales were calculated to find out mean and standard deviation and then translated based on criteria developed by Best (1981) as follows:

5 refers to The highest level

$4 \quad$ refers to High level

3 refers to Moderate level

2 refers to Low level

$1 \quad$ refers to The lowest level

This, then, is calculated into mean scores as a following formulation.

$1.00 \leq \overline{\mathrm{X}}<1.50$ refers to the lowest level.

$1.51 \leq \overline{\mathrm{X}}<2.50$ refers to low level.

$2.51 \leq \overline{\mathrm{X}}<3.50$ refers to moderate level.

$3.51 \leq \overline{\mathrm{X}}<4.50$ refers to high level.

$4.51 \leq \overline{\mathrm{X}}<5.00$ refers to the highest level. 
The collected data was analyzed using a computer program. The statistics used for analyzing the data were Frequency, Mean scores, Standard Deviation, t-Test, F-Test and content analysis.

\section{Results}

\section{Results of the demographic data of the respondents}

Table 1: Results of the Demographic Data of the Respondents

\begin{tabular}{lll}
\hline Demographic data of the respondents & $\mathbf{n}$ & Percentage \\
\hline Gender & & \\
\hline Male & 41 & 29.30 \\
\hline Female & 99 & 70.70 \\
\hline Total & $\mathbf{1 4 0}$ & $\mathbf{1 0 0}$ \\
\hline Age & 0 & \\
\hline Less than 20 years old & 0 \\
\hline 20-30 years old & 19 & 13.60 \\
\hline $31-40$ years old & 84 & 60.00 \\
\hline More than 40 years old & 37 & 26.40 \\
\hline Total & $\mathbf{1 4 0}$ & $\mathbf{1 0 0}$ \\
\hline Educational background & & \\
\hline Less than Bachelor degree & 21 & 15.00 \\
\hline Bachelor degree & 93 & 66.40 \\
\hline Master degree and above & 26 & 18.60 \\
\hline Total & $\mathbf{1 4 0}$ & $\mathbf{1 0 0}$ \\
\hline
\end{tabular}

Table 1 showed that the majority of respondents was female (70.70\%) whose age was between 31-40 years old (60\%) with Bachelor degree $(66.40 \%)$.

Table 2: Results of the Place and Investment of the Respondents

\begin{tabular}{lllll}
\hline Investment & \multicolumn{3}{l}{ Place } & \multicolumn{2}{l}{ Rental } & \% \\
\cline { 2 - 5 } & Owner & $\mathbf{n}$ & $\mathbf{n}$ & 21.00 \\
\hline Less than 500,000 Baht & 10 & 25.00 & 21 & 54.00 \\
\hline $500,001-1,000,000$ Baht & 17 & 42.50 & 54 & 14.00 \\
\hline $1,000,001-1,500,000$ Baht & 5 & 12.50 & 14 & 11.00 \\
\hline More than 1,500,000 Baht & 8 & 20.00 & 11 & $\mathbf{1 0 0}$ \\
\hline Total & $\mathbf{4 0}$ & $\mathbf{1 0 0}$ & $\mathbf{1 0 0}$ & \\
\hline
\end{tabular}

The table showed that 54 percent of the respondents rented the place with the investment budget at 500,001-1,000,000 Baht.

Table 3: Results of Entrepreneurs divided by business capital, entrepreneur experiences and numbers of staff

\begin{tabular}{|c|c|c|}
\hline Variables & $\mathbf{n}$ & Percentage \\
\hline \multicolumn{3}{|l|}{ Business capital } \\
\hline Less than $50,000 \mathrm{Baht}$ & 43 & 30.70 \\
\hline $50,001-100,000$ Baht & 79 & 56.40 \\
\hline More than 100,001 Baht & 18 & 12.90 \\
\hline Total & 140 & 100 \\
\hline \multicolumn{3}{|l|}{ Entrepreneur experience } \\
\hline $1-3$ years & 44 & 31.30 \\
\hline 4-6 years & 45 & 32.20 \\
\hline $7-10$ years & 30 & 21.40 \\
\hline More than 10 years & 21 & 15.00 \\
\hline Total & 140 & 100 \\
\hline \multicolumn{3}{|l|}{ Number of staff } \\
\hline $1-5$ & 88 & 60.70 \\
\hline $6-10$ & 23 & 16.30 \\
\hline $11-15$ & 20 & 14.30 \\
\hline More than 15 & 12 & 8.70 \\
\hline Total & 140 & 100 \\
\hline
\end{tabular}


The table showed that there was $56.40 \%$ of respondents invested 50,001-100,000 Baht for business capital. For entrepreneur experience, there was $32.20 \%$ of respondents had 4-6 years of entrepreneur experience. For number of staff, there was $60.70 \%$ of respondents had 1-5 staff.

\section{Results of desired characteristics of successful start-up entrepreneurs in Prachuap Kirikhan province}

Table 4: Mean $(\overline{\mathrm{X}})$ and Standard Deviation (S.D.) of desired characteristics of successful start-up entrepreneurs in Prachuap Kirikhan province in Overall

\begin{tabular}{|c|c|c|c|c|}
\hline No. & Aspects & $\overline{\mathrm{X}}$ & S.D. & Level \\
\hline 1. & Risk taking & 4.44 & 0.32 & High \\
\hline 2. & Patience & 4.73 & 0.31 & Highest \\
\hline 3. & Human Relationship & 4.31 & 0.54 & High \\
\hline 4. & Motivation and Ambition & 4.03 & 0.74 & High \\
\hline 5. & Knowledge and Experience Backgrounds & 4.71 & 0.45 & Highest \\
\hline 6. & Vision and Mission & 4.66 & 0.462 & Highest \\
\hline 7. & Information Search & 4.46 & 0.453 & High \\
\hline 8. & Creativity & 4.63 & 0.448 & Highest \\
\hline 9. & Confidence & 4.43 & 0.642 & High \\
\hline 10. & Innovation and Responsibility & 4.26 & 0.669 & High \\
\hline 11 & Opportunity seeking & 4.34 & 0.834 & High \\
\hline 12. & Honest & 4.57 & 0.752 & Highest \\
\hline Total & & 4.47 & 0.24 & High \\
\hline
\end{tabular}

The above table indicated that desired characteristics of successful start-up entrepreneurs in Prachuap Kirikhan province in overall was at a high level $\left(\bar{X}_{=4.47)}\right.$. The highest rank at the highest level was Patience $(\overline{\mathrm{X}}=4.73)$, followed by Knowledge and Experience Backgrounds $(\overline{\mathrm{X}}=4.71)$ whereas the lowest rank at a high level was Motivation and Ambition $(\overline{\mathrm{X}}=4.03)$.

Table 5: Comparison of desired characteristics of successful start-up entrepreneurs in Prachuap Kirikhan province according to Gender

\begin{tabular}{|c|c|c|c|c|c|}
\hline $\begin{array}{l}\text { Successful } \\
\text { entrepreneurs }\end{array}$ & Gender & $\overline{\mathrm{X}}$ & S.D. & $\mathbf{t}$ & $\mathbf{p}$ \\
\hline \multirow{2}{*}{ Successful start-up entrepreneurs } & Male & 4.34 & 0.57 & \multirow[t]{2}{*}{-2.986} & \multirow[t]{2}{*}{$0.003 * *$} \\
\hline & Female & 4.62 & 0.48 & & \\
\hline
\end{tabular}

* Statistically significant differences at 0.01 level

The table showed that successful start-up entrepreneurs with different gender had statistically significant differences at 0.01 ( $\mathrm{p}=$ 0.003).

Table 6: Comparison of desired characteristics of successful start-up entrepreneurs in Prachuap Kirikhan province according to Age, Educational background, Investment, Business capital, Entrepreneur experience and Number of staffs

\begin{tabular}{|c|c|c|c|c|c|c|c|}
\hline No. & Components & & SS & df & MS & $\mathbf{F}$ & $\mathbf{p}$ \\
\hline \multirow[t]{3}{*}{1.} & \multirow[t]{3}{*}{ Age } & Between Groups & .898 & 2 & 0.449 & 1.625 & 0.201 \\
\hline & & Within Groups & 37.845 & 137 & 0.276 & & \\
\hline & & Total & 38.743 & 139 & & & \\
\hline \multirow[t]{3}{*}{2.} & \multirow{3}{*}{$\begin{array}{l}\text { Educational } \\
\text { background }\end{array}$} & Between Groups & 2.783 & 2 & 1.391 & 5.301 & $0.00 * *$ \\
\hline & & Within Groups & 35.960 & 137 & 0.262 & & \\
\hline & & Total & 38.743 & 139 & & & \\
\hline \multirow[t]{3}{*}{3.} & \multirow[t]{3}{*}{ Investment } & Between Groups & 1.069 & 3 & 0.356 & 1.286 & 0.282 \\
\hline & & Within Groups & 37.674 & 136 & 0.277 & & \\
\hline & & Total & 38.743 & 139 & & & \\
\hline \multirow[t]{3}{*}{4.} & \multirow[t]{3}{*}{ Business capital } & Between Groups & 0.600 & 2 & 0.600 & 2.170 & 0.143 \\
\hline & & Within Groups & 38.143 & 137 & 0.276 & & \\
\hline & & Total & 38.743 & 139 & & & \\
\hline \multirow[t]{3}{*}{5.} & \multirow{3}{*}{$\begin{array}{l}\text { Entrepreneur } \\
\text { experience }\end{array}$} & Between Groups & 0.681 & 3 & 0.227 & 0.811 & 0.490 \\
\hline & & Within Groups & 38.062 & 136 & 0.280 & & \\
\hline & & Total & 38.743 & 139 & & & \\
\hline \multirow[t]{3}{*}{6.} & \multirow[t]{3}{*}{ Number of staff } & Between Groups & 5.540 & 3 & 1.847 & 7.564 & $0.00 * *$ \\
\hline & & Within Groups & 33.203 & 136 & 0.244 & & \\
\hline & & Total & 38.743 & 139 & & & \\
\hline
\end{tabular}

* Statistically significant differences at 0.01 level 
The above table showed that successful start-up entrepreneurs had statistically significant differences at 0.01 level in educational background and number of staff.

\section{Conclusions}

The findings indicated that desired characteristics of successful start-up entrepreneurs in Prachuap Kirikhan province in overall was at a high level. The highest rank at the highest level was Patience, followed by Knowledge and Experience Backgrounds whereas the lowest rank at a high level was Motivation and Ambition. For the comparisons, it was shown that different gender, educational background and number of staffs had statistically significant differences at 0.01 level. The additional suggestions were remarkably emphasized on using past and present experiences to adapt with the business; using technological advancement to reach a wider target group; and using new creativity and risk taking to make a brand uniqueness. According to Deáková, et al. (2010), the most important personal qualities for an entrepreneur are: courage, self-reliance, responsibility, determination, perseverance, proactive approach, creativity and scholarship in a particular area, where this entrepreneur intends to do business. This is supported by the statement of Kvietok (2013) who advocates that decision to take on the business risk is symptomatic of a certain type of people. A significant part of the motivation to take risks in business follows from the success motivation.

To achieve the set goals, successful people are willing to take on reasonable risks associated with feedback about the level of achieved results. In this way, it might be concluded that entrepreneurs are sort of being managed with an inner feeling, which means that they feel that their personal fate is the result of their own efforts. They are independent, autonomous, and rely on themselves, what are the characteristics of entrepreneurial personalities. Achievement Cluster, therefore, should be recognized by the entrepreneurs. The Cluster is divided into five categories as Opportunity Seeking; Commitment to the work contract; Persistence; Demand for efficiency and quality; and Risk taking.

\section{References}

Best, J. (1981). Research in education (4th ed.). New Jersey: Prentice Hall.

Canabal, A. and O'Donnell, E. (2009). It's not only about what you want, but also how much you want it: Developing a new theoretical perspective on entrepreneurial motivation. Frontiers of Entrepreneurship Research, 29, 130.

Deakins, D. (1999). Entrepreneurship and Small Firms, London: McGrawHill.

Deáková, K., Drážovská, K., Grznárik, D., Kondášová, I. (2010). Entrepreneurship. Bratislava: SOPK.

Etzkowitz, H. (2003). Research groups as 'quasi-firms: the invention of the entrepreneurial university, Research Policy, 32, 1, 109121

Farsi, J., Imanipour, N. and Salamzadeh, A. (2012). Entrepreneurial university conceptualization: case of developing countries, Global Business and Management Research: An International Journal, 4, 2, 193-204.

Franke, N. and Lüthje, C. (2004). Entrepreneurial intentions of business students - a benchmarking study. International Journal of Innovation and Technology Management, 1, 3, 269-288.

Gibb, A.A. (1993). Enterprise culture and education understanding enterprise education and its links with small business, entrepreneurship and wider educational goals, International Small Business Journal, 11, 3, 11-34.

Jeon, Y. and Nah, K. (2014). Policies supporting design to vitalize one-man designer creation business: Focus on a startup, one-man creation businesses in design and fashion at the DaeguGyeongbuk Design Center. Korea Des. Forum, 43, 31-42.

Kao, R.W.Y. (1989) Entrepreneurship and Enterprise Development, Holt, Rinehart \& Winston of Canada.

Kodama, F. and Shibata, T. (2017). Beyond fusion towards IoT by way of open innovation: An investigation based on the Japanese machine tool industry 1975-2015. J. Open Innov. Technol. Mark. Complex, 3, 23.

Kvietok, A. (2013). Psychological profile of the entrepreneur. Retrieved March 24, 2014, Retrieved from http://www.psyx.cz/texty/psychologickyprofilpodnikatele.php.

Lawless, M., McCannand, F., and Calder, T. (2014). SMEs in Ireland: Contributions, credit and economic crisis. Policy Stud., 35, 435-457.

Mazzarol, T., Volery, T., Doss, N. and Thein, V. (1999). Factors influencing small business start-ups: a comparison with previous research, International Journal of Entrepreneurial Behaviour \& Research, 5, 2, 48-63

McClelland, D.C. (1965). N achievement and entrepreneurship: a longitudinal study, Journal of Personality and Social Psychology, $1,4,389-392$

Othman, M.N., Ghazali, E. and Sung, Y.S. (2006). Graduate versus non- graduate entrepreneurs in urban Malaysia: some insights into entrepreneurial personality, company and family background differences, Journal of International Business and Entrepreneurship Development, 3, Nos. 1/2, 57-75.

Palmer, M. (1971). The application of psychological testing to entrepreneurial potential, California Management Review, 13, 3, 3239.

Peterson, R. (1985). Creating contexts for new ventures in stagnating environments, Frontiers of Entrepreneurship Research, Babson College.

Wellesley, AM. Tengeh, R. and Nkem, L. (2017). Sustaining immigrant entrepreneurship in South Africa: The role of informal financial associations. Sustainability, 9, 1396.

Shane, S. and Venkataraman, S. (2001). Entrepreneurship as a field of research: 
a response to Zahra and Dess, Singh, and Erikson, Academy of Management Review, 26, 1, 13-16.

Thurik, A.R. (2009). Entreprenomics: entrepreneurship, economic growth and policy', in Z.J. Acs, D.B. Audretsch and R. Strom (Eds.): Entrepreneurship, Growth and Public Policy, 219-249, Cambridge University Press, New York.

Welsh, J.A. and White, J.F. (1981). Converging on characteristics of entrepreneurs, in K.H. Vesper (Ed.), Frontiers of Entrepreneurship Research, 504-515.

Publisher's Note: SSBFNET stays neutral with regard to jurisdictional claims in published maps and institutional affiliations.

\section{(c) (1)}

(C) 2021 by the authors. Licensee SSBFNET, Istanbul, Turkey. This article is an open access article distributed under the terms and conditions of the Creative Commons Attribution (CC BY) license (http://creativecommons.org/licenses/by/4.0/).

International Journal of Research in Business and Social Science (2147-4478) by SSBFNET is licensed under a Creative Commons Attribution 4.0 International License. 